\title{
ATP and adenosine prevent via different pathways the activation of caspases in apoptotic AKR-2B fibroblasts
}

\author{
Jürgen Hoppe ${ }^{\star, 1}$, Rolf Schäfer ${ }^{1}$, Viviane Hoppe ${ }^{1}$ and \\ Agapios Sachinidis $^{2}$ \\ ${ }^{1}$ Department of Physiological Chemistry, Biozentrum, University of Würzburg \\ Am Hubland, 97074 Würzburg, Germany \\ 2 Medizinische Universitats-Poliklinik, Wilhelmstr. 35-37,53111 Bonn, Germany \\ * corresponding author: J. Hoppe, Department of Physiological Chemistry, \\ Biozentrum, University of Würzburg, Am Hubland, 97074 Würzburg, \\ Germany. tel: +0931 888 4130, fax: +0931 8884123
}

Received: 19.08.98; revised: 9.02.99; accepted: 16.03 .99

Edited by P. Nicotera

\begin{abstract}
Abbreviations: BSA, bovine serum albumin; DEVD-pNA, asp-gluval-asp-paranitranilide; DMSO, dimethyl sulfoxide; DPMX, 1,3dipropyl-7-methylxanthine; DTT, dithiothreitol; EGTA, ethyleneglycol-bis ( $\beta$-aminoethyl ether) $\mathrm{N}, \mathrm{N}, \mathrm{N}^{\prime}, \mathrm{N}^{\prime}$-tetraacetic acid; MAPTAM, 1,2-bis(o-amino-5'-methylphenoxy)ethane- $N, N^{\prime}, N^{\prime}, N^{\prime}$, tetraacetic acid tetraacetoxymethylester; PBS, phosphate buffered saline; PDGF, platelet-derived growth factor; PMSF, phenylmethylsulfonyl fluoride; PKC, protein kinase C; PPADS, pyridoxalphosphate-6-azophenyl-2',4'-disulfonic acid; PTX, pertussis toxin; TPA, phorbol-12-myristate-13-acetate; VEID-pNA, val-glu-ile-aspparanitranilide
\end{abstract}

\section{Introduction}

Selective cell death plays an important role in determining population size in specific groups of cells. The survival of many types of cells is critically dependent on the presence of specific growth factors or yet undefined serum components. In contrast to necrosis, which is a consequence of the plasma membrane disruption due to chemical or physical insult, that kind of cell death, termed apoptosis, is an active process of the target cell. Apoptosis appears in many facets, but certain morphological and biochemical changes are recurrent. For most of the investigated cells, the early events of cell death are characterized by a condensation of chromatin followed by a fragmentation of the DNA yielding a 'DNA ladder' (for review see ${ }^{1-11}$ ). The collapsed nucleus frequently breaks up into spheres forming 'apoptotic bodies'. Finally these particles are engulfed either by macrophages or by neighbouring cells.

The emerging view of apoptosis is that diverse regulatory pathways activate a common execution machinery which carries out cell disassembly. Although this execution machinery is poorly understood, it appears that an essential component is the caspases family, cysteine proteases which are activated by proteolytic cleavage from precursor proteins. Caspases cleave their substrates after an aspartate residue, a very unusual substrate specificity for eukaryotic proteases. This family of enzymes consisting of caspase-1 (ICE), caspase-2 (ICH-1), caspase-3 (CPP32/ Yama/apopain), caspase-4 (ICE-rellI/TX/ICH-2), caspase-5 (ICErel-III/TY), caspase-6 (Mch2), caspase-7 (Mch3/ICELAP3/CMH-1), caspase-8 (FLICE/MACH/Mch5), caspase-9 (ICE-LAP/Mch6), caspase-10 (Mch4), caspase-11 and caspase-12 has been suggested to play a central part in the apoptotic process. ${ }^{12-14}$

On the other hand, the disruption of the mitochondrial inner transmembrane potential $\left(\Delta \Psi_{\mathrm{m}}\right)$ marks a point of no return for the apoptotic cascade. Two mitochondrial proapoptotic factors have been purified: the $15 \mathrm{kD}$ cytochrom c protein which acts together with cytosolic factors, ${ }^{15-17}$ and a $50 \mathrm{kD}$ protease that by itself suffices to cause nuclear apoptosis. ${ }^{18}$ 
Another family of proteins whose function in regulating apoptosis is phylogenetically conserved, is the $\mathrm{Bcl}-2$ protein family. ${ }^{19}$ Some members of this family, e.g. human Bcl-2, $\mathrm{Bcl}-\mathrm{X}_{\mathrm{L}}$, Ced-9 and the adenovirus E1B $19 \mathrm{kD}$ protein are able to inhibit apoptosis. Other members, such as Bax, $\mathrm{Bad}, \mathrm{Bcl}-\mathrm{X}_{\mathrm{S}}$ and Bak have the opposing effect of promoting cell death. Most recently the interaction of some members of this family with signal transduction components related to proliferation control has been identified shedding some light on the mechanism by which growth factors and associated signalling pathways may prevent apoptosis. ${ }^{11,20,21}$

Density arrested fibroblasts like Balbc/3T3 or AKR-2B cells die after serum deprivation. Depending on the cell line, death after serum removal is either immediately initiated (Balbc/3T3) $)^{22-25}$ or starts after a delay of 90 min (AKR-2B). ${ }^{26,27}$ Dying of the cells ceases after $5-6 \mathrm{~h}$ with a survival of $10-20 \%$ (Balbc/3T3) or $50 \%$ (AKR-2B). Morphological changes are quite similar for both cell lines including membrane blebbing and chromatin condensation. These are typical characteristics for apoptosis, but remarkably there is no DNA fragmentation. Furthermore both cell types die by membrane disrupture. This unusual behaviour has been recently characterized in detail for AKR-2B cells. ${ }^{27}$

Adenosine has been recognized as cell protecting agent, especially for cellular protection after heart attack followed by ischaemic conditions. ${ }^{28-30}$ It has been shown that ATP has some mitogenic effect on 3T3 mouse fibroblasts that is not due to breakdown products like adenosine. In some cases it acts synergistically with other growth factors. ${ }^{31-34}$ As recently shown, ATP might also induce cell death by activation of P2X-receptors (for review see ${ }^{35}$ ).

We show here that ATP as well as adenosine suppressed cell death with high efficiency in AKR-2B fibroblasts after serum deprivation. By different criteria we excluded the possibility that the effect of ATP was due to a degradation into adenosine. In order to define some intracellular pathways possibly involved in cell protection, a limited number of metabolites or protein kinases was analyzed. Clearly, ATP produced a strong rise in $\left[\mathrm{Ca}^{2+}\right]_{\mathrm{i}}$, lead to the activation of MAP-kinase, RSK, and $p 70^{\mathrm{S6}}$. kinase and a decrease in the cAMP content. On the contrary adenosine led to a strong rise in intracellular cAMP and had no effect on $\left[\mathrm{Ca}^{2+}\right]_{\mathrm{i}}$, MAP-kinase-, RSK- or p70 ${ }^{\mathrm{S6}}$. kinase-activation. However, the signalling pathways stimulated by both ATP or adenosine must converge at the caspases, the activation of which is prevented, thereby suppressing cell death.

\section{Results}

\section{Cell protection by ATP and adenosine}

AKR-2B cells rapidly disintegrate after serum removal. After a delay of about 90 min the number of viable cells rapidly declines and reaches a plateau after $6-12 \mathrm{~h}$ of about $40-$ $50 \%$ of the initial cell number (cf. Figure 2). As previously shown protective reagents might be assigned to two classes: (a) those requiring protein synthesis for long term protection; typical effectors belonging to this class are PDGF-BB and TPA, (b) substances not requiring protein biosynthesis for protection, e.g reagents stimulating the increase in intracellular cAMP-content (e.g. forskolin or 8-Br-cAMP). ${ }^{22-25,36}$ In Figure 1 the protective effects of ATP and adenosine after serum deprivation were determined after $6 \mathrm{~h}$ (short term) and $24 \mathrm{~h}$ (long term). Both reagents were able to protect cells from death over a long time periode although the protective effect was somewhat lower (77\%) after $24 \mathrm{~h}$ than that after $6 \mathrm{~h}$

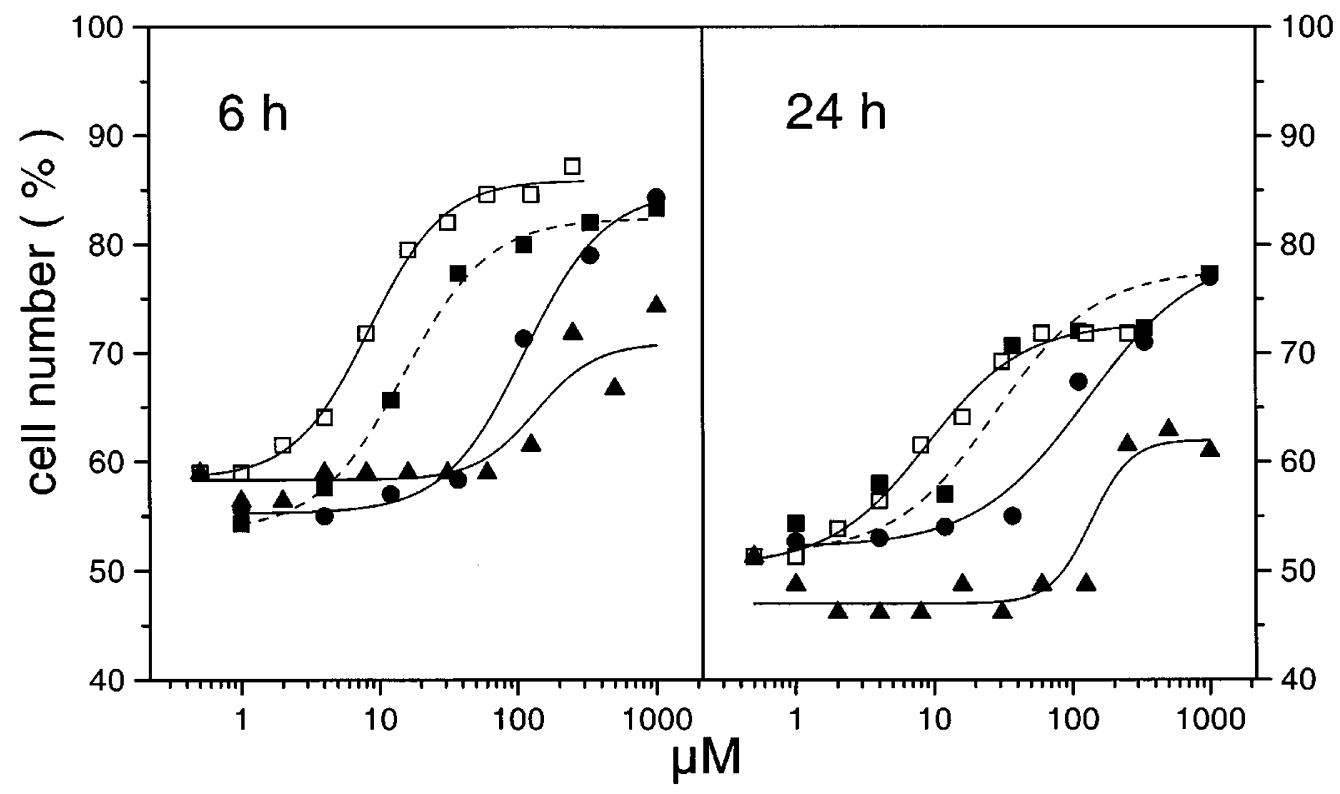

Figure 1 Protective effect of adenosine and ATP on AKR-2B cells after serum deprivation. AKR-2B cells were grown in 24 well plates in McCoy 5 A medium containing $5 \%$ Hyclone calf serum to confluency. Immediately after medium change to serum free MCDB 402 medium, the indicated compounds were added. Number of viable cells was determined after 6 or $24 \mathrm{~h}$, respectively. Data were fitted using the four parameters logistic curve fitting of the program 'origin'. Individual points are means of triplicates. ATP - $\mathbf{\square}$; ATP- $[\gamma \mathrm{S}]-\square$; adenosine $-\mathbf{0} ; 2$-methylthio-ATP $-\boldsymbol{\Delta}$ 
(85\%). The $\mathrm{ED}_{50}$ values for ATP were $14 \mu \mathrm{M}(6 \mathrm{~h})$ and $28 \mu \mathrm{M}$ (24 h), respectively, and for adenosine $110 \mu \mathrm{M}(6 \mathrm{~h})$ and $130 \mu \mathrm{M}(24 \mathrm{~h})$, respectively, indicating that for both times similar effective doses are required.

In order to describe the specificity of ATP-effect, a series of nucleotide triphosphates was examinated in the concentration range up to $1 \mathrm{mM}$. Among these compounds only ATP- $[\gamma \mathrm{S}] \quad\left(\mathrm{ED}_{50}=8.4 \mu \mathrm{M}\right)$ could substitute ATP. 2methylthio-ATP $\left(E D_{50}=135 \mu \mathrm{M}\right)$ did not lead to a similar maximal protection compared to ATP (Figure 1). ADP had only a slight effect: protection after $6 \mathrm{~h}$ was about $10 \%$ over control and was even lower after $24 \mathrm{~h}$. AMP was inactive. The adenine base could not be replaced by other common bases, e.g. guanosine, uridine and cytidine (GTP, UTP and CTP). Further derivatives containing a non hydrolysable $\beta, \gamma$ linkage $\left(\beta, \gamma-\mathrm{NH}-\mathrm{ATP}\right.$ and $\beta, \gamma-\mathrm{CH}_{2}$-ATP) were uneffective. Likewise $\alpha-\beta-\mathrm{CH}_{2}$-ATP was also inactive. Furthermore benzoylbenzoyl-ATP and oxidized ATP had no protective effect. Three commonly used antagonist for purinergic receptors (P2-receptors) were tested in the concentration range up to $1 \mathrm{mM}$ in the presence of $100 \mu \mathrm{M}$ ATP: (1) oxidized ATP ${ }^{37}$ was not an inhibitor of ATP, (2) suramin reduced cell number by itself even in the presence of serum $\left(E D_{50}=150 \mu \mathrm{M}\right)$ and (3) PPADS did not alter the cell number either in the absence or presence of serum nor in the presence of $100 \mu \mathrm{M}$ ATP. These results suggest a specific interaction with a cellular receptor $\left(E D_{50}=14 \mu \mathrm{M}\right)$ that is selective for an adenine base and most likely requires hydrolysis of $\beta, \gamma$-linkage in ATP. Although these data do not allow a pharmacological identification of a selective purinergic receptor among the numerous described isoforms, the low $\mathrm{ED}_{50}$ value of $14 \mu \mathrm{M}$ for ATP

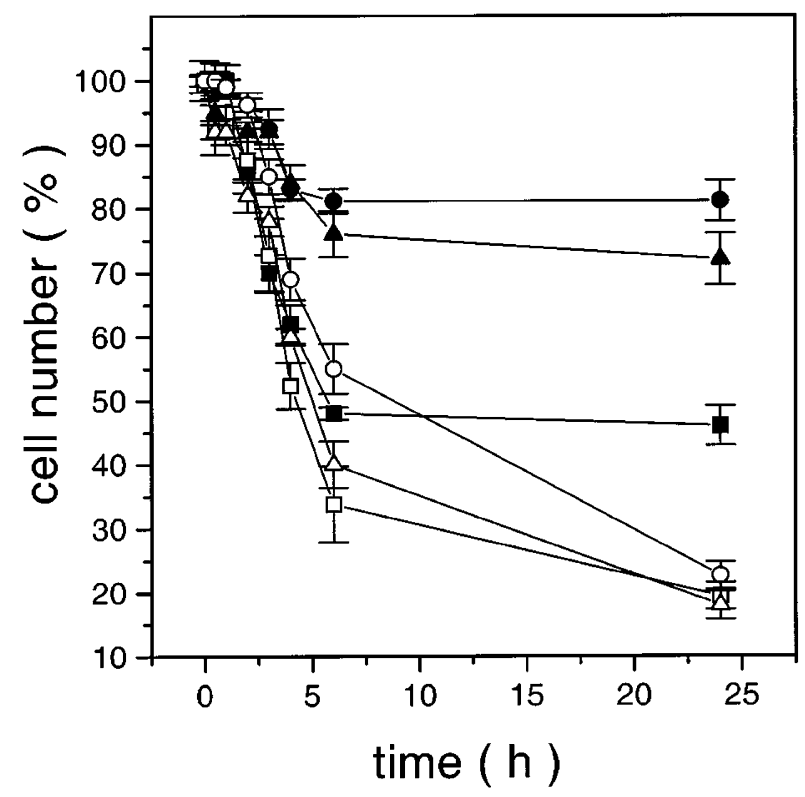

Figure 2 Requirement of protein synthesis for cell protection by ATP or adenosine. Cells were prepared as above. PDGF-BB, ATP or adenosine in the absence or presence of $5 \mu \mathrm{g} / \mathrm{ml}$ cycloheximide $(\mathrm{CHx})$ were added immediately after serum deprivation. Viable cells were counted after the indicated time. Control - $\square ;+5 \mu \mathrm{g} / \mathrm{ml} \mathrm{CHx}-\square ;+100 \mu \mathrm{M}$ ATP $-\boldsymbol{\Delta} ;+100 \mu \mathrm{M} \mathrm{ATP}+5 \mu \mathrm{g} / \mathrm{ml} \mathrm{CHx}$ $-\triangle ;+1 \mathrm{mM}$ adenosine $-0 ;+1 \mathrm{mM}$ adenosine $+5 \mu \mathrm{g} / \mathrm{ml} \mathrm{CHx}-\bigcirc$ suggests the involvement of a membrane bound receptor, since the ATP concentration in AKR-2B cells is $6 \mathrm{mM}$. Moreover, one can exclude the possibility that adenosine as a breakdown product of ATP mediates the response since the $E D_{50}$-value for adenosine is ten times higher $\left(E D_{50}=110 \mu \mathrm{M}\right)$.

In order to understand the role of adenosine, two xanthine antogonists were tested in the concentration range up to $300 \mu \mathrm{M}$ in the presence of $500 \mu \mathrm{M}$ adenosine. DPMX as well as 8-phenyltheophyllin did not show any inhibitory effects. Unlike for ATP it remains to be identified for adenosine whether the binding to a membrane bound receptor is responsible for the protective effect.

We have furthermore investigated whether the protective effect of ATP or adenosine relies on protein synthesis. Figure 2 shows the time dependency of cell death in the presence or absence of cycloheximide $(\mathrm{CHx})$. In the absence of $\mathrm{CHx}$ both ATP and adenosine are potent cell survival factors. In the presence of $\mathrm{CHx}$ after $6 \mathrm{~h}$ the level of cells was close to control values. After $24 \mathrm{~h}$ almost all cells were dead, and their number was far below control. Clearly for both ATP and adenosine protein synthesis is needed. $\mathrm{CHx}$ itself leads to slow decay in cell number even in the presence of serum. About $10-15 \%$ of cells are lost after $6 \mathrm{~h}$ in the presence of 5 or $50 \mu \mathrm{M} \mathrm{CHx}, 10 \%$ are lost after $24 \mathrm{~h}$ using $5 \mu \mathrm{M}$ and $40 \%$ are lost after $24 \mathrm{~h}$ incubation time applying $50 \mu \mathrm{M} \mathrm{CHx}$ (data not shown). In the absence of serum $\mathrm{CHx}$ leads to rapid and complete cell death Figure 2. ${ }^{36}$ Thus, protein synthesis is required for the maintainance of cells in presence of serum as well as for those cells that survived serum deprivation.

\section{Modulation of growth response to PDGF-isoforms}

Neither ATP nor adenosine promote cell division as shown in Figure 3B. Adenosine blocks completely PDGF-BB induced cell division. ATP had no effect (Figure 3A). These results suggest that ATP and adenosine act via different intracellular pathways and again exclude the possibility that the ATP effects are due to the degradation product adenosine.

\section{ATP and adenosine stimulate distinct intracellular pathways}

The above results suggested the involvement of different intracellular pathways induced by either ATP or adenosine. Two common intracellular messengers were analyzed: cAMP and $\left[\mathrm{Ca}^{2+}\right]_{i}$. Figure 4 shows that after serum deprivation both adenosine and forskolin as positive control condition substantially raised the intracellular content of cAMP from 0.42 to $1.5 \mu \mathrm{M}$. The effect was maximal after 2-5 min and gradually declined during $60 \mathrm{~min}$. Upon serum removal as a control the cAMP level dropped by $50 \%$. An even stronger drop was observed when ATP was added: cAMP values decreased to almost zero. Thus, adenosine strongly stimulated the cAMP production whereas on the contrary ATP caused a decrease in cAMP content.

The opposite situation was seen with $\left[\mathrm{Ca}^{2+}\right]_{i}$ (Figure 5). ATP evoked a tremendous increase from 0.05 up to $0.8 \mu \mathrm{M}$ intracellular $\mathrm{Ca}^{2+}$ after a very short time of $15 \mathrm{~s}$. The signal 
was short and decayed to baseline after $100 \mathrm{~s}$ (Figure 5A). In the absence of extracellular $\mathrm{Ca}^{2+}$ the signal is considerably shortened, indicating the uptake of external $\mathrm{Ca}^{2+}$ from the medium (Figure $5 \mathrm{~B}$ ). The $\mathrm{ED}_{50}$ values from both experiments were identical $(7 \mu \mathrm{M})$ suggesting that a common receptor was activated (Figure 5A insert). Furthermore the obtained $\mathrm{ED}_{50}$ corroborates well with that of $14 \mu \mathrm{M}$ for cell protection. Adenosine virtually had no effect. For comparison the effect of PDGF-BB was rather slow and weak, since a maximum of $300-400 \mathrm{nM}\left[\mathrm{Ca}^{2+}\right]_{\mathrm{i}}$ was found after $1 \mathrm{~min}^{38}$ In summary, the results show again that ATP and adenosine act via different intracellular pathways.

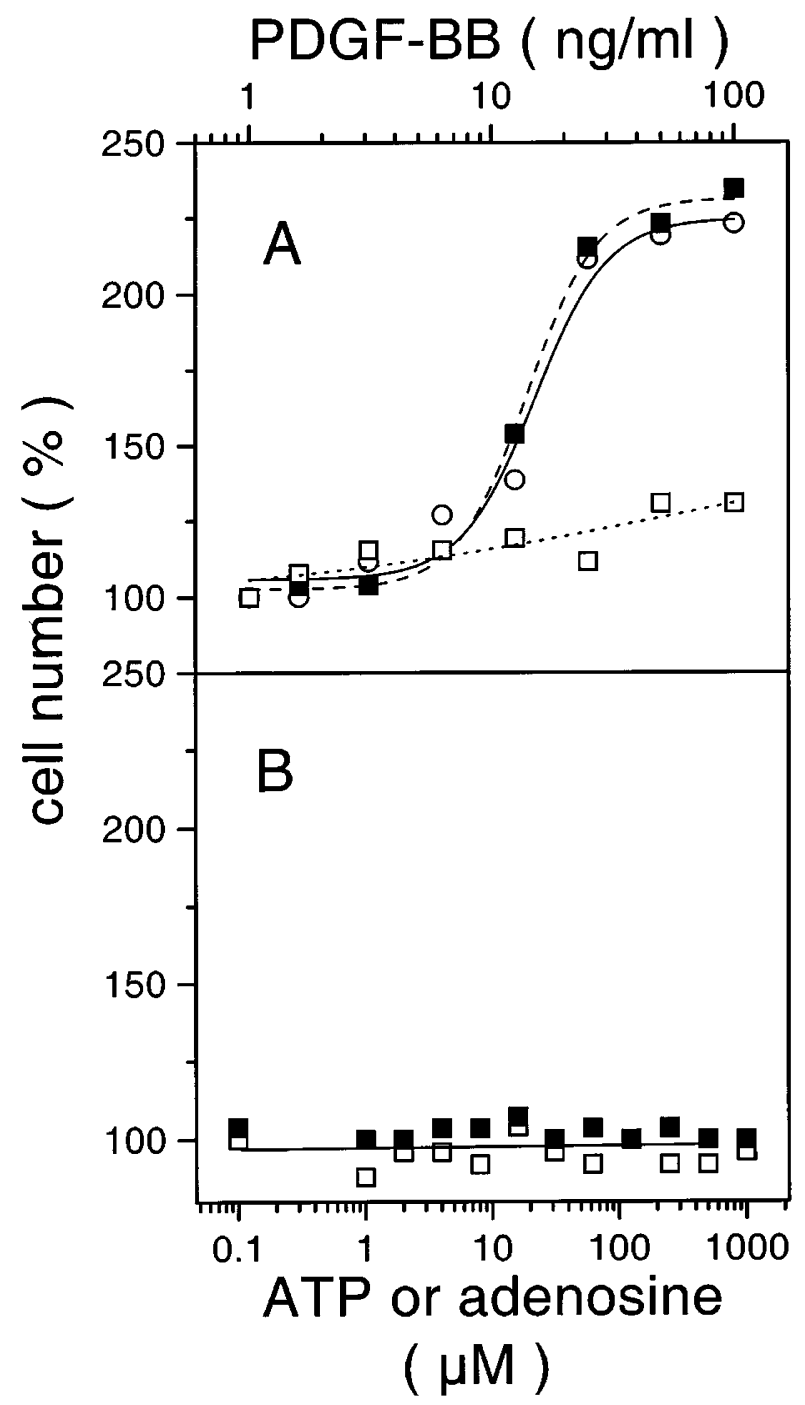

Figure 3 Effect of adenosine or ATP on the proliferation of AKR-2B cells Cells were grown to confluency in McCoy $5 \mathrm{~A}$ medium in the presence of $5 \%$ Hyclone and were transfered to MCDB 402 medium without further supplement. Two days later the factors were added at the indicated concentrations. After $36 \mathrm{~h}$ cell number was counted by the CASY-1 system. (A) PDGF-BB - O; PDGF-BB+100 $\mu$ M ATP - - ; PDGF-BB +1 mM adenosine $\square$; (B) ATP - $\mathbf{\square}$; adenosine - $\square$
To investigate the role of $\left[\mathrm{Ca}^{2+}\right]_{i}$ in the signalling pathway involved in the protection by ATP, $\left[\mathrm{Ca}^{2+}\right]_{i}$ was complexed with the ligand MAPTAM. As shown in Figure $5 \mathrm{C}$ there was no increase in $\left[\mathrm{Ca}^{2+}\right]_{i}$ after treatment with the $20 \mu \mathrm{M}$ MAPTAM. In Figure 6 the effect of this treatment on the protection by various reagents after serum removal is shown. First, complexation of $\left[\mathrm{Ca}^{2+}\right]_{i}$ had no effect on cells kept in McCoy medium containing serum, excluding the possibility that MAPTAM treatment alone caused cell death. On the other hand MAPTAM treatment did not prevent cell death induced by serum deprivation. Thus in both control experiments, complexation of $\left[\mathrm{Ca}^{2+}\right]_{i}$ had no effect. MAPTAM treatment did not reduce the protective effects of either PDGF-BB, forskolin or adenosine. This result was expected for adenosine and forskolin which did not lead to an increase in $\left[\mathrm{Ca}^{2+}\right]_{i}$ as shown above. But surprisingly the protection by PDGF-BB was maintained although this compound provoked a significant increase in $\left[\mathrm{Ca}^{2+}\right]_{i}$ as described earlier. ${ }^{26,38}$ Interestingly the protection by ATP was significantly reduced indicating a participation of $\left[\mathrm{Ca}^{2+}\right]_{i}$ in the protective signalling pathway by ATP (Figure 6).

There are two types of ATP receptors termed $\mathrm{P} 2 \mathrm{X}$ or $\mathrm{P} 2 \mathrm{Y}$. $\mathrm{P} 2 \mathrm{X}$ receptors are plasma membrane ligand gated ion channels activated by ATP, whereas $P 2 Y$ receptors act via G-proteins (for review see ${ }^{35,39}$ ). Upon activation of $\mathrm{P}_{2} \mathrm{X}_{7}$ receptors, channels are opened which are permeable to a variety of ions, including ethidiumbromid. ${ }^{40,41}$ We have therefore incubated AKR-2B cells with $2 \mu \mathrm{g} / \mathrm{ml}$ ethidiumbromide after stimulation with ATP. Over an observation

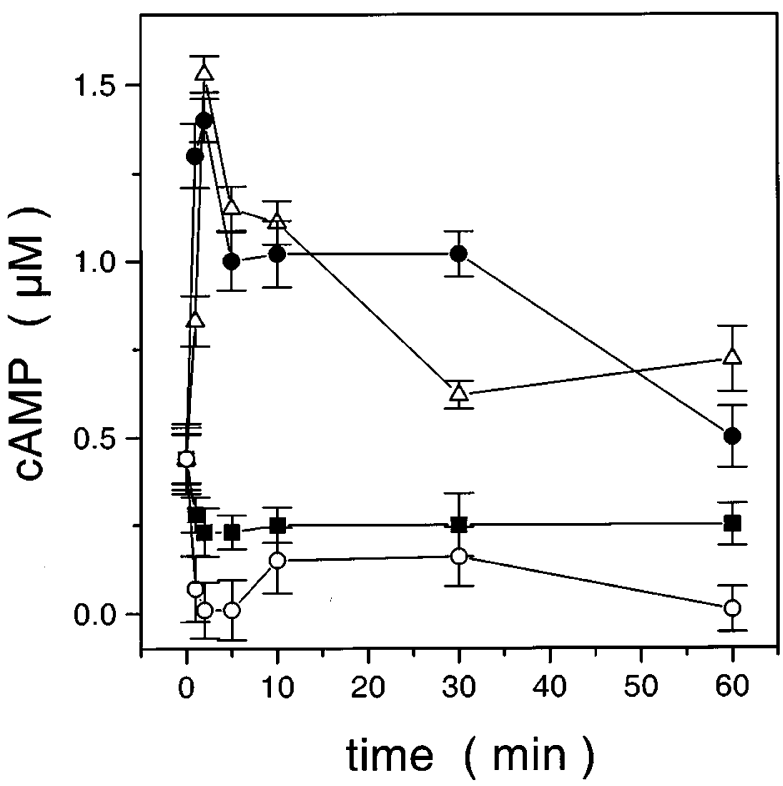

Figure 4 Effects of ATP or adenosine on the intracellular concentrations of cAMP. Cells were grown as described in Figure 1, and the indicated amounts of effectors were added immediately after serum deprivation. After the indicated time cells were lysed and the cAMP content was determined as described by the supplier. Cell volumes were determined by the CASY-1 system of Schärfe using the Coulter Counter principe. Finally, cAMP values were transformed in concentrations per cell. Thus, resting cells had a basal concentration of $0.4 \mu \mathrm{M}$ cAMP. Control (serum deprivation) - $\mathbf{\square} ;+1 \mathrm{mM}$ adenosine $-\triangle ;+5 \mu \mathrm{M}$ forskolin - $;+100 \mu \mathrm{M}$ ATP - 0 
time of 90 min there was no uptake of this dye (data not shown). Apparently this receptor isoform is not involved in the protection from cell death in AKR-2B cells by ATP. To demonstrate a role of G-proteins, cells were treated with pertussis toxin (PTX) an inactivator of $G_{i}$-proteins. As shown in Figure 7 PTX had no effect in control
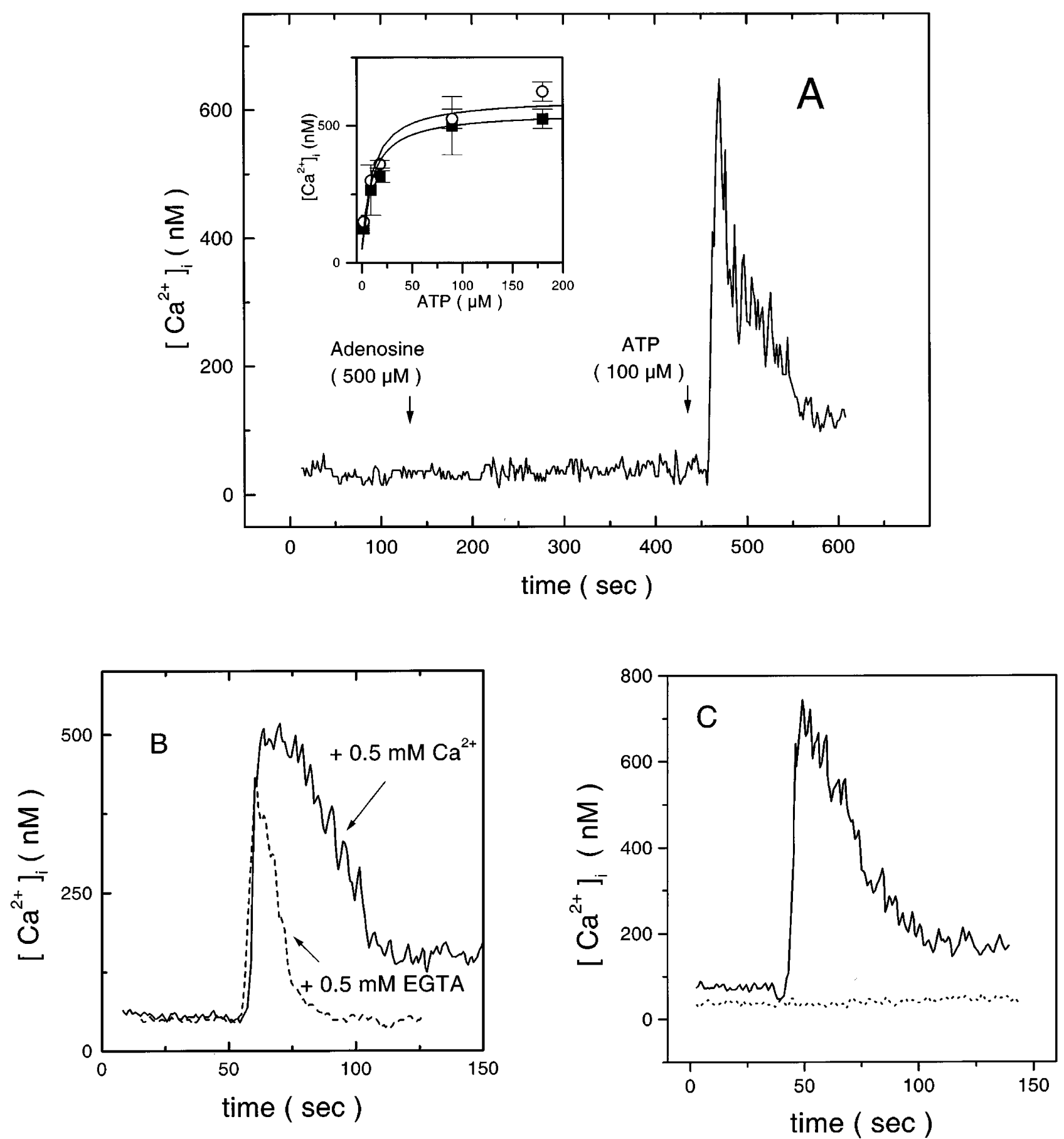

Figure 5 Effects of ATP or adenosine on the intracellular concentrations of $\left[\mathrm{Ca}^{2+}\right]_{\mathrm{i}}(\mathrm{A})$ Cells were grown on glass cover slides and were loaded with fura-2AM. After mounting in the spectrofluorimeter, adenosine $(500 \mu \mathrm{M})$ was added as indicated by the arrow. After a period of $400 \mathrm{~s}$ the same sample received ATP $(100 \mu \mathrm{M})$

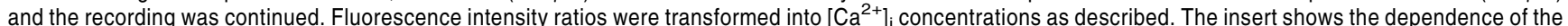
$\left[\mathrm{Ca}^{2+}\right]_{i}$ either in the presence $(-\mathrm{O})$ or the absence $(-\mathbf{O})$ of extracellular $\mathrm{Ca}^{2+}$ from the applied ATP concentration. An $\mathrm{ED}_{50}$ value of $7 \mu \mathrm{M}$ was calculated by curve fitting from both experiments. (B) Dependence of the $\left[\mathrm{Ca}^{2+}\right]_{i}$-signal from extracellular $\mathrm{Ca}^{2+}$. Measurements were performed as described above. The standard reaction mixture contains $0.5 \mathrm{mM} \mathrm{Ca}{ }^{2+}$. To measure the effect of external $\mathrm{Ca}^{2+}, 1 \mathrm{mM} \mathrm{EGTA}$ was added to $\mathrm{Ca}^{2+}$ - free reaction buffer. The reaction was initiated by the addition of $100 \mu \mathrm{M}$ ATP. (C) Suppression of the $\left[\mathrm{Ca}^{2+}\right]_{i}$-signal after preincubation with MAPTAM. Cells were incubated for 15 min with $20 \mu \mathrm{M}$ MAPTAM in McCoy medium containing serum prior to stimulation with $100 \mu \mathrm{M}$ ATP (dotted line); control (straight line) 
experiments, i.e. it neither induced nor inhibited cell death on its own. But the protective effect of ATP was significantly reduced after preincubation with PTX.

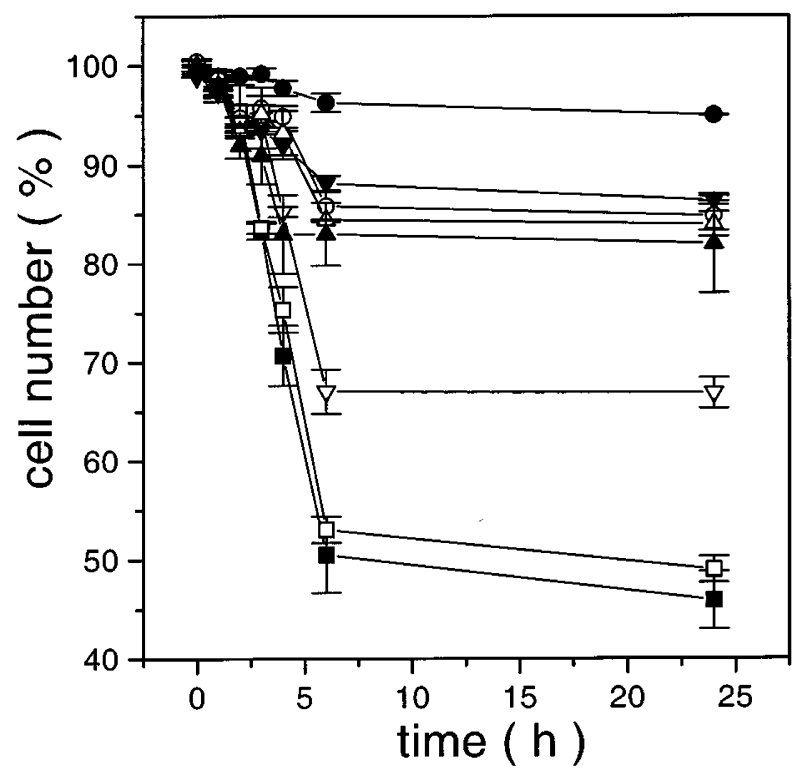

Figure 6 Effect of MAPTAM preincubation on the protective effect of various reagents. Cells were grown in 24 well plates in McCoy $5 \mathrm{~A}$ medium containing $5 \%$ Hyclone calf serum to confluency. They were incubated for $15 \mathrm{~min}$ with $20 \mu \mathrm{M}$ MAPTAM. Afterwards the medium was replaced by serum free MCDB 402 medium with the respective additives. Cells were counted after the indicated times. McCoy medium containing serum+MAPTAM - $\mathbf{0}$; serum free MCDB 402 medium: control - $\mathbf{\square}$; +MAPTAM - $\square$; $+50 \mathrm{ng} / \mathrm{ml}$ PDGFBB+MAPTAM - $; ;+100 \mu \mathrm{M}$ ATP $-\mathbf{\nabla} ;+100 \mu \mathrm{M}$ ATP+MAPTAM $-\nabla ;+5 \mu \mathrm{M}$ forskolin+MAPTAM $-\boldsymbol{\Delta} ;+500 \mu \mathrm{M}$ adenosine+MAPTAM $-\triangle$
The high increase in $\left[\mathrm{Ca}^{2+}\right]_{\mathrm{i}}$ led to the hypothesis that PKC-isoforms (for review on PKC-isoforms see ${ }^{42-44}$ ) might be involved in the later signal transduction, since we have

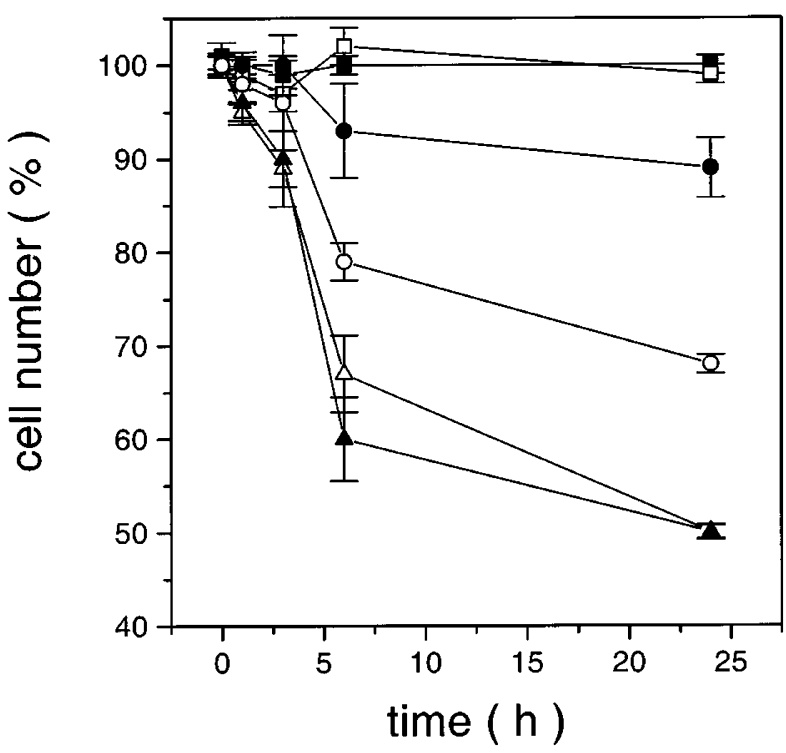

Figure 7 Effect of pertussis toxin pretreatment on the protective effect of ATP AKR-2B cells were grown in McCoy $5 \mathrm{~A}$ medium containing $5 \%$ Hyclone calf serum. If indicated $3 \mathrm{~h}$ before serum removal and replacement with MCDB 402 medium, cells were treated with $100 \mathrm{ng} / \mathrm{ml}$ pertussis toxin (PTX). If indicated immediately after serum removal $100 \mu \mathrm{M}$ ATP was added. Cells kept in McCoy medium containing serum-,; cells kept in McCoy medium containing serum+PTX - $\square$; cells after serum removal $-\mathbf{\Delta}$; cells after serum removal+PTX $-\triangle$; cells after serum removal $+100 \mu \mathrm{M}$ ATP $-\boldsymbol{\bullet}$; cells after serum removal $+100 \mu \mathrm{M}$ ATP + PTX -0

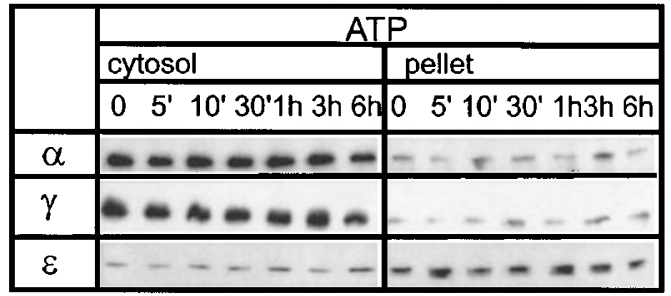

\begin{tabular}{|l|l|l|}
\hline \multirow{2}{*}{} & \multicolumn{2}{|c|}{ TPA } \\
\cline { 2 - 3 } & cytosol & pellet \\
\cline { 2 - 3 } & $05^{\prime} 10^{\prime} 30^{\prime} 1 \mathrm{~h} 3 \mathrm{~h} 6 \mathrm{~h}$ & $05^{\prime} 10^{\prime} 30^{\prime} 1 \mathrm{~h} 3 \mathrm{~h} 6 \mathrm{~h}$ \\
\hline$\alpha$ & - & - \\
\hline$\gamma$ & $-\ldots-$ & $-\cdots$ \\
\hline$\varepsilon$ & - & $-\cdots$ \\
\hline
\end{tabular}

Figure 8 Effects of TPA or ATP on PKC-isoforms. Left: expression of various PKC-isoforms and downregulation after chronic TPA-treatment. Ten $\mu \mathrm{g}$ protein of an SDS-lysate was analyzed per lane. Blots were processed for chemiluminescence detection as decribed in Materials and Methods. For the downregulation of selective PKC-isoforms, cells were incubated overnight in McCoy medium containing serum with $1 \mu \mathrm{M}$ TPA. Right: cells were prepared as described in Figure 1 and then treated either with $100 \mu \mathrm{M}$ ATP or with $100 \mathrm{nM}$ TPA. After mechanical disruption a cytosolic extract was prepared by ultracentrifugation. The pellet was extracted with buffer containing $2 \%$ Triton X-100. Aliquots of $10 \mu \mathrm{g}$ protein were subjected to SDS-gel-electrophoresis. After blotting onto nitrocellulose the blots were probed with antibodies against the isoforms $\alpha, \gamma$, and $\epsilon$ 
shown previously that TPA led to a high protection against cell death. ${ }^{36}$ The expression of PKC-isoforms in AKR-2B cells is shown in Figure 8. In comparison with control experiments using extracts from rat brain or Jurkat cells it was verified that AKR-2B cells did not express the isoforms $\beta, \delta$, and $\Theta$. As shown in Figure 8 after chronical treatment with $1 \mu \mathrm{M}$ TPA overnight, there were only residual amount of PKC- $\gamma$, PKC- $\alpha$ completely disappeared, and there was some reduction of $\mathrm{PKC}-\varepsilon$. Furthermore it was investigated whether TPA or ATP treatment, respectively, led to a changement in the subcellular distribution of certain isoforms. In Figure 8 only those results are presented that demonstrate an altered subcellular distribution. Clearly TPA induced a drastic translocation of $\mathrm{PKC} \alpha, \gamma$ and $\varepsilon$ from the cytosol to the particulate matter from the cytosol. On the other hand, ATP was completely inactive.

In Figure 9 the effect of the downregulation of the PKCisoforms on the protection by PDGF-BB, TPA or ATP, respectively, was studied. After chronical treatment with $1 \mu \mathrm{M}$ TPA more cells were resistant towards serum removal ( $70 \%$ surviving cells ). As expected, the readdition of TPA (100 nM) did not lead to a further protection. On the other hand PDGF-BB was completely protective, even after $24 \mathrm{~h}$, and the ATP protection profil was also almost unmodified (Figures 2 and 9). In summary these results do not indicate an involvement of PKC-isoforms in the mechanism of cell protection by ATP and PDGF-BB, respectively.

To further gain some knowledge in subsequent activation of target protein kinase, the effect of the ATP or adenosine on three 'mitogen activated protein kinases' (MAP-kinase, p70 ${ }^{\mathrm{S} 6}$-kinase and RSK) were investigated. All three kinases are activated by phosphorylation. The extent of phosphorylation can be analyzed by a bandshift, since phosphorylated forms migrate somewhat slower. For all three kinases the correlation between activation and the appearance of a slow mobility form has been well documented. ${ }^{45-48}$ As shown in Figure 10, adenosine did not significantly activated any of the investigated kinases. In contrast, ATP activated all three kinases, though the duration of the activation for the MAP-kinase was significantly shorter than that evoked by PDGF-BB. ${ }^{38,39}$
We have recently shown that the activation of a CPP32 like caspase (caspase 3 ) is a hallmark in the mechanism of cell death in AKR-2B cells. The activation of this enzyme was inhibited by all applied cell protecting reagents, including PDGF-BB, TPA or forskolin. ${ }^{36}$ In Figure 11 it is shown that also ATP or adenosine led to a complete suppression of DEVDase (caspase 3) and VEIDase (caspase 6) activation in AKR-2B cells. Thus these experiments establish the eminent role of this type of caspases and further demonstrate that the diverse signals generated by either ATP or adenosine must converge at this point.

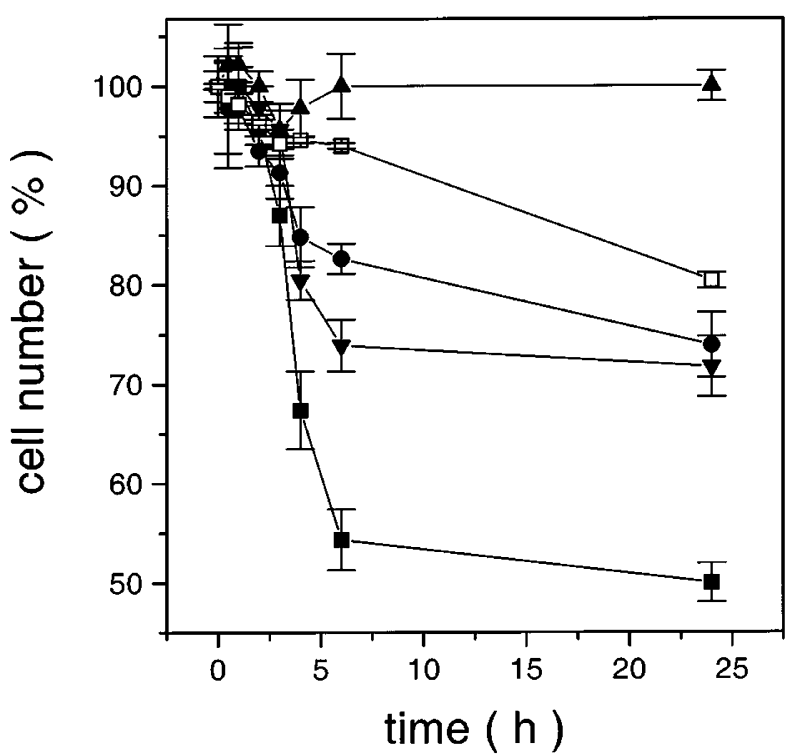

Figure 9 Effect of the downregulation of PKC isoforms on the protective effects of PDGF-BB, ATP or TPA. AKR-2 cells were first grown in McCoy medium containing $5 \%$ Hyclone calf serum to confluency and then treated in this medium with $1 \mu \mathrm{M}$ TPA over night. For stimulation this medium was removed and replaced by serum free MCDB 402 medium. Immediately after serum removal $50 \mathrm{ng} / \mathrm{ml}$ PDGF-BB - $\boldsymbol{\Delta}, 100 \mu \mathrm{M}$ ATP - $\square$ or $100 \mathrm{nM}$ TPA - $\boldsymbol{\nabla}$ were added. Control cells in MCDB pretreated with $1 \mu \mathrm{M}$ TPA - $\mathbf{0}$; control cells in MCDB without preincubation -

\begin{tabular}{|c|c|c|c|c|}
\hline & PDGF-BB & ATP & adenosine & \\
\hline time $(\min )$ & $\begin{array}{lllll}0 & 2 & 5 & 153060\end{array}$ & $\begin{array}{llllll}0 & 2 & 5 & 15 & 30 & 60\end{array}$ & $\begin{array}{llllll}0 & 2 & 5 & 15 & 30 & 60\end{array}$ & \\
\hline MAPK & 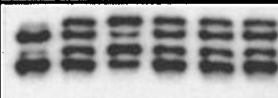 & 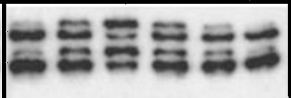 & 8 & $\begin{array}{l}\leftarrow 44 \mathrm{kD} \\
\leftarrow 42 \mathrm{kD}\end{array}$ \\
\hline $\mathrm{p} 70^{\text {s6k }}$ & 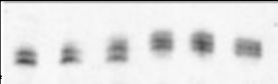 & 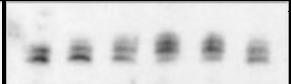 & 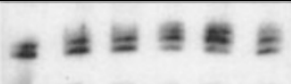 & $\leftarrow 70 \mathrm{kD}$ \\
\hline RSK & 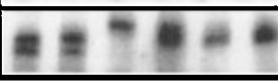 & 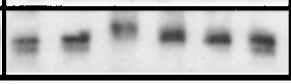 & $=m=m=-$ & $\leftarrow 90 \mathrm{kD}$ \\
\hline
\end{tabular}

Figure 10 Effect of adenosine or ATP on various mitogen activated protein kinases. Cells were grown to confluency and were kept for 2 days in MCDB 402 without serum. The factors were then added for the indicated time (adenosine $500 \mu \mathrm{M}$; ATP $100 \mu \mathrm{M}$ ). Cells were lysed in SDS-containing buffer and prepared for gelelectrophoresis as described in Materials and Methods. After transfer to nitrocellulose the protein kinases were detected by specific antibodies followed by chemiluminescence as described 


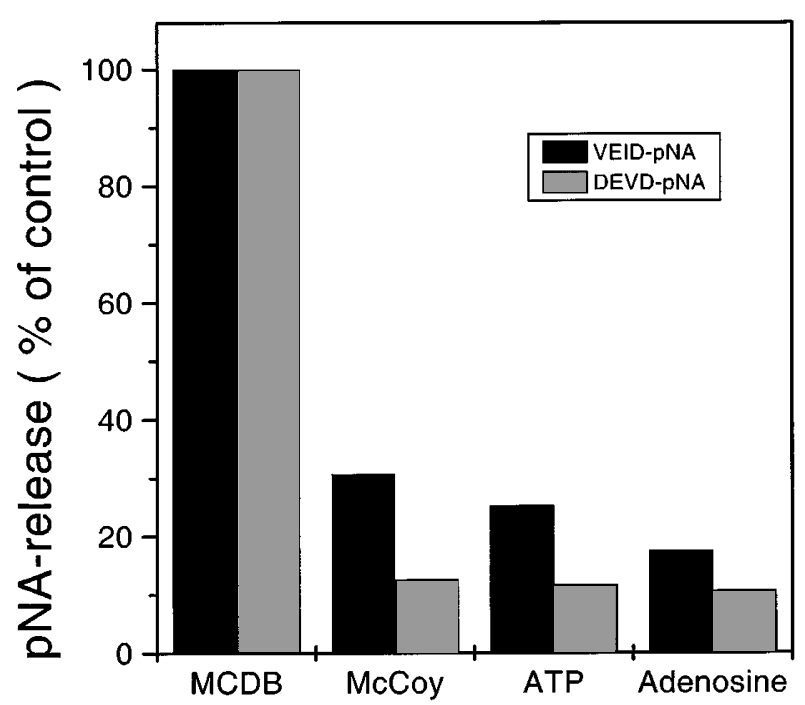

Figure 11 ATP or adenosine interfere with the activation of caspases. Cells were cultivated as described. If indicated immediately after serum removal either $100 \mu \mathrm{M}$ ATP or $1 \mathrm{mM}$ adenosine was added. After $3 \mathrm{~h}$ cells were mechanically disrupted and a cytosolic extract was prepared by ultracentrifugation. DEVDase- or VEIDase activities were measured spectrophotometrically in an Elisa reader by the release of $p$-nitroaniline from the respective peptides DEVD-pNA or VEID-pNA. Values were normalized to $100 \%$ in the absence of adenosine or ATP

\section{Discussion}

Although adenosine has been recognized as a cell protecting reagent. $^{28-30}$ Indeed, in AKR-2B cells there was a strong increase of cAMP 2 min after the addition of adenosine, comparable to that evoked by forskolin. But unlike for forskolin or $8 \mathrm{Br}$-cAMP, cell death occurred in the presence of the protein synthesis inhibitor cycloheximide. ${ }^{36}$ Thus, protection by forskolin and $8 \mathrm{Br}$-cAMP is independent from protein synthesis in contrast to adenosine. The reason for this discrepancy is not clear but possibly adenosine affects also other pathways so far unidentified which leads to requirement of protein synthesis.

Evidence accumulated over almost 20 years has shown that many different cell types are killed by sustained exposure to high concentrations of extracellular ATP. The plasma membrane receptors involved have been pharmacologically characterized and cloned during the last 3 years, and named purinergic P2X. P2X receptors share an intriguing structural relatedness with Caenorhabditis elegans degenerins and mammalian amiloride-sensitive $\mathrm{Na}^{+}$ channels. Depending on the ATP dose, length of stimulation and receptor subtype, $\mathrm{P} 2 \mathrm{X}$ receptor stimulation may cause necrosis or apoptosis. P2X receptors are plasma membrane ligand-gated ion channels activated by ATP. ${ }^{50,51}$ They belong to the growing family of receptors for extracellular nucleotides named P2 purinergic receptors whose other members are the P2Y receptors, ${ }^{39,52,53}$ while plasma membrane receptors that bind adenosine are referred to as purinergic P1. According to current classification of plasma membrane receptors for neurotransmitters, $\mathrm{P} 2 \mathrm{X}$ and $\mathrm{P} 2 \mathrm{Y}$ receptors are also often referred to as ionotropic and metabotropic, respectively. ${ }^{50}$ The intracellular pathways activated are poorly known, but the perturbation in intracellular ion homeostasis clearly plays a major role. ICE proteases (caspases) are also triggered, nonetheless their activation is not requested for ATPdependent cell death. The physiological meaning of P2X receptor-dependent cytotoxicity is not understood, but an involvement in immune-mediated reactions is postulated (for review see $^{35}$ ).

In contrast to the above observations we describe here for the first time a protective effect of ATP on AKR-2B cells. These cells rapidly disintegrated after serum removal. After a delay of about 90 min death occurs exponentially with a half time of $3.5 \mathrm{~h}$ reaching a plateau of $40-50 \%$ of the initial cell number after $6-8 \mathrm{~h} .{ }^{26,27}$ A detailed characterization of morphological changes and biochemical events reveal several features in common with programmed cell death-apoptosis. These include nuclear condensation, membrane blebbing and the involvement of ICE-like proteases in the onset of cell death. But unlike to many other cell systems these events were paralleled by membrane disruption as detected by electric permeability. Likewise there was no engulfment and ingestion by neighbouring cells. ${ }^{27}$

The results from two different experiments show that P2X-receptors do not seem to be involved in the signalling pathway stimulated by ATP: firstly, there was no opening of pores permitting the uptake of ethidiumbromide, which is common to many ATP-dependent ionic channels, secondly the selective inhibitor oxidized ATP was without effect.

The P2Y family encompasses selective purinoreceptors (for review see ${ }^{39}$ ) (the $\mathrm{P}_{2} \mathrm{Y}_{1}$ receptors activated preferentially by ADP and ATP), nucleotide receptors responsive to both adenine and uracil nucleotides (the $\mathrm{P}_{2} \mathrm{Y}_{2}$ receptors activated equipotently by ATP and UTP, and the $\mathrm{P}_{2} \mathrm{Y}_{8}$ receptors activated equally by all triphosphate nucleotides), and pyrimidinoreceptors (the $\mathrm{P}_{2} \mathrm{Y}_{3}$ and $\mathrm{P}_{2} \mathrm{Y}_{6}$ receptors activated preferentially by UDP and the $\mathrm{P}_{2} \mathrm{Y}_{4}$ receptors activated preferentially by UTP). All these P2Y subtypes are coupled exclusively to the phosphoinositide pathway. $\mathrm{P}^{2} \mathrm{Y}_{5}$ receptors exhibit an unusual strict requirement for ATP. Likewise a recently cloned receptor $\mathrm{P}_{2} \mathrm{Y}_{11}$ which couples to both phospholipase $C$ and adenylyl cyclase accepts only ATP and 2-methylthio-ATP as ligand. By using a series of nucleotide analogues we have demonstrated a similar high selectivity for ATP. Only ATP- $[\gamma-S]$ could substitute for ATP, while 2-methylthio-ATP was only partially active. All other tested compounds including $\alpha$ - $\beta$ methylene-ATP were without effect. Thus the participation of the receptors $P 2 Y_{1-4,6,8}$ can largely be excluded. In contrast to the $P 2 Y_{11}$ receptor which couples to the adenylyl cyclase, ATP added to AKR-2B cells led to a strong drop in the cAMP-content. It therefore remains to be determined whether or which of the known receptors is involved in the ATP-dependent protection. The ATPinduced drop in the cAMP content could be cause by the activation of $\mathrm{Ca}^{2+}$ dependent cAMP-phosphodiesterases or by an inhibitory G-protein $\left(G_{i}\right)$. Indeed we found that pretreatment of the cells with pertussis toxin partially reversed the protective effect by ATP, suggesting an 
involvement of $\mathrm{G}_{\mathrm{i}}$-proteins in the signaling pathway leading to protection by this nucleotide.

A second important signal generated is $\left[\mathrm{Ca}^{2+}\right]_{i}$. After intracellular complexation with MAPTAM the protective effect of ATP was blunted, but interestingly not that by PDGF-BB. As expected there was no effect on the protection evoked by adenosine which acts via CAMP and does not lead to a rise in $\left[\mathrm{Ca}^{2+}\right]_{\mathrm{i}}$.

ATP stimulates MAP-kinase, $p 70^{\mathrm{S} 6}$-kinase and RSK. However, as described previously activation of these pathway does not correlate with the protection of AKR-2B cells. ${ }^{36}$ On the other hand members of the protein kinase $C$ family play a role in the prevention of cell death. ${ }^{36}$ We therefore investigated whether ATP led to an activation of PKC family members. Based on the translocation assay there was no evidence for an activation of any PKC isoforms by the addition of exogeneous ATP. Furthermore after downregulation of the isoforms $\alpha$ and $\gamma$, the protective effect still persisted. Although we have demonstrated the activation of several pathways, the nature of the protective effect remains obscure. But two components seem to be involved: $\mathrm{G}_{\mathrm{i}}$-proteins and $\left[\mathrm{Ca}^{2+}\right]_{i}$. Remarkably these two compounds enlarge the list of intracellular messengers and pathways which interfere with death in AKR-2B cells. As previously described PDGF-BB, forskolin, 8-Br-cAMP, TPA, okadaic acid as well as colchicine counteracted the induction of cell death induced by serum deprivation and all these compounds abolished the activation of a CPP32like protease (caspase-3). ${ }^{36}$ We show here that ATP as well as adenosine suppressed the activation of DEVDase(caspase-3 substrate) and VEIDase- (caspase-6 substrate) activities. Thus all these reagents converge at the activation of caspases by a plethora of different and independent pathways, including the rise of cAMP, $\left[\mathrm{Ca}^{2+}\right]_{i}$, the activation of $\mathrm{G}_{\mathrm{i}}$ proteins, inhibition of phosphatases and also the involvement of the cytoskeleton.

In summary, this article describes the protection against apoptosis afforded by two common compounds ATP and adenosine, which obviously regulate different pathways, disclosing a novel function for ATP.

\section{Materials and Methods}

PDGF was prepared as described. ${ }^{54,55}$ Nucleotides were purchased from Sigma (Deisenhofen, Germany). Cell culture reagents were purchased from Gibco (Eggenstein, Germany). Antibodies against p70 ${ }^{\text {S6 }}$-kinase, RSK were from Biomol (Hamburg, Germany). Antibodies against MAP-kinase were from Santa Cruz (Heidelberg, Germany). The cAMP-kit was from Amersham (Braunschweig, Germany). Antibodies against PKC isoforms were from Transduction Laboratories (Dianova, Hamburg, Germany), ATP-derivatives, pertussis toxin, PPADS and suramin were from Sigma. 2-methylthio-ATP and DPMX were from ICN (Eschwege, Germany). Secondary antibodies were from Dianova (Hamburg, Germany). DEVDpNA and VEIDpNA were from Bachem (Heidelberg, Germany). MAPTAM was from Calbiochem (Bad Soden, Germany).

\section{Cell number of synchronized confluent cells}

Stock cultures of AKR-2B mouse fibroblasts were propagated in antibiotic-free McCoy-5A medium with $5 \%$ Hyclone calf serum for less than 3 months to minimise fluctuations. During that time responses to PDGF did not change. Cells were prepared for the stimulation with various reagents using the protocol originally described by Shipley et al. ${ }^{56}$ Briefly, experimental cultures were seeded at a density of $5 \times 10^{3}$ cells $/ \mathrm{cm}^{2}$ into 24 well plastic dishes (Falcon) and grown for 5 days in McCoy-5A medium containing $5 \%$ calf serum (Hyclone) without a medium change. For the measurement of cell survival, cells were washed twice with MCDB-402 medium without serum. Immediately after, the respective tested compound was added. The number of viable cells was determined by using the CASY-1 system (Schrfe, Reutlingen, Germany) based on the Coulter Counter principle. For the determination of mitogenic activity cells were starved in MCDB-402 medium for 2 days (cells were arrested and synchronized), then fresh MCDB-402 medium with indicated factors was added. Cell number was determined as above using the CASY-1 system.

\section{Determination of CAMP}

For determination of the cAMP content, cells were grown in 6 well plates. For termination of the reaction, cells were washed briefly with MCDB medium and subsequently lysed in 60\% methanol. After filtration through reversed phase chromatography material Nucleosil C18, $7 \mu \mathrm{m}$ (Macherey and Nagel, Düren, Germany) the filtrate was dried and the residue was taken up in $40 \mu \mathrm{l}$ water. The CAMP content in this extract was then determined with the Amersham kit (Braunschweig, Germany). Cell number and volume were determined with the CASY-1 sytem, thus allowing the calculation of the intracellular CAMP content.

\section{Measurement of $\left[\mathrm{Ca}^{2+}\right]_{\mathrm{i}}$}

The cells were cultured on round glass microscope slides $(12 \mathrm{~mm}$ diameter) under normal tissue culture conditions. Confluent cells were incubated with $2 \mu \mathrm{M}$ fura-2-pentaacetoxymethyl ester (fura-2AM) at $37^{\circ} \mathrm{C}$ for $20 \mathrm{~min}$ in HEPES-buffer (20 mM HEPES, $16 \mathrm{mM}$ glucose, $130 \mathrm{mM} \mathrm{NaCl}, 1 \mathrm{mM} \mathrm{MgSO} 4.7 \mathrm{H}_{2} \mathrm{O}, 0.5 \mathrm{mM} \mathrm{CaCl}, \mathrm{pH} 7.4$ ) supplemented with $1 \%$ bovine serum albumin (BSA) $(\mathrm{w} / \mathrm{v})$. Just prior to measurements, the cell monolayers were rinsed with HEPES buffer containing $1 \mathrm{mM} \mathrm{CaCl}_{2}$, the glass slide was positioned diagonally in the cuvette and measurements were performed in $2 \mathrm{ml}$ HEPES buffer containing $1 \mathrm{mM} \mathrm{CaCl}_{2}$. The $\mathrm{Ca}^{2+}$-fura-2-fluorescence was measured at $37^{\circ} \mathrm{C}$ in a LS50 Perkin Elmer spectrofluorometer (Überlingen, Germany ) at excitation wavelengths of 340 and $380 \mathrm{~nm}$ and an emission wavelength of $505 \mathrm{~nm}$. Fluorescence was corrected for cellular autofluorescence and was calibrated. ${ }^{38,57,58}$

\section{Gel electrophoresis and immunostaining}

SDS-polyacrylamide gel electrophoresis was performed essentially as described $^{59}$ using $8 \%$ acrylamide gels for RSK, PKC-isoforms and p $70^{\mathrm{S} 6}$-kinase, $12 \%$ for MAP-kinase $(30 / 0.3$ (w/w) acrylamide/ bisacrylamide). Mini gels of $0.75 \mathrm{~mm}$ thickness were used (BioRad Mini Protean). Cells were grown in 24 well plates $\left(1.75 \mathrm{~cm}^{2}\right.$ surface/ well) and were lysed in $50 \mu$ l buffer containing $50 \mathrm{mM}$ Tris-Cl, $\mathrm{pH}$ 6.7, $2 \%$ SDS, $2 \%$ mercaptoethanol and $0.1 \mathrm{mM}$ sodium orthovanadate. After 5 min vigorous shaking $10 \mu$ l benzonase solution were added (low concentration (Merck) to a final concentration of $1 \%$ ) and shaking was continued for another $5 \mathrm{~min}$. The entire solution was transfered to a micro test tube and $6 \mu \mathrm{l}$ of a bromphenol blue solution in $50 \%$ glycerol was added. Five microlitres were taken for electrophoresis. Proteins were transfered onto reinforced nitrocellulose by semi-dry blotting using $50 \mathrm{mM}$ CAPS, pH 10.0, $1 \mathrm{mM}$ 3-mercaptopropionic acid, $0.1 \%$ SDS and $10 \%$ methanol as blotting buffer for $1 \mathrm{~h}$ at $6 \mathrm{~V}$. The 
nitrocellulose sheet was washed once with $50 \mathrm{mM}$ Tris- $\mathrm{Cl}, \mathrm{pH} 7.5$ $150 \mathrm{mM} \mathrm{NaCl}$ (TS buffer). Saturation was performed for $1 \mathrm{~h}$ with $2 \%$ bovine serum albumin (BSA), $0.2 \%$ Triton $X-100$ in TS plus $0.03 \%$ $\mathrm{NaN}_{3}$ (TSBT). The sheets were incubated for $1 \mathrm{~h}$ with the antibodies against MAP-kinases $(0.2 \mu \mathrm{g} / \mathrm{ml}), \mathrm{RSK}, \mathrm{p} 70 \mathrm{S6}$-kinase or PKCisoforms $(1 \mu \mathrm{g} / \mathrm{ml})$ with the exception of PKC- $\gamma(0.1 \mu \mathrm{g} / \mathrm{ml})$ in TSBT. After washing six times with TS containing $0.5 \%$ BSA, $0.2 \%$ Triton $X$ 100 without $\mathrm{NaN}_{3}$ (washing buffer) the sheets were incubated for $1 \mathrm{~h}$ with goat-antirabbit or sheep-antimouse IgG antibodies labelled with horse radish peroxydase at a dilution of $1 / 10000$ in TSBT without $\mathrm{NaN}_{3}$. The antibody was removed by washing six times with washing buffer, and the sheets were prepared for luminescence reaction as described. ${ }^{26}$

\section{Determination of caspase activity}

All steps were performed at $4^{\circ} \mathrm{C}$. Cells grown on $10 \mathrm{~cm}$ culture dishes were rinsed in $10 \mathrm{ml}$ PBS and scraped in $200 \mu \mathrm{l}$ extraction buffer (50 mM HEPES- $\mathrm{NaOH}, \mathrm{pH} 7.0,50 \mathrm{mM} \mathrm{KCl}, 5 \mathrm{mM}$ EGTA, $2 \mathrm{mM}$ $\mathrm{MgCl}_{2}, 1 \mathrm{mM}$ PMSF). They were disrupted with a mini ultra turrax and homogenate was clarified by a 20 min centrifugation at $100000 \times \mathrm{g}$. The supernatant was frozen at $-80^{\circ} \mathrm{C}$. All experiments described in the present study were performed within 1 week after preparation of the extract. Seventy-five microgrammes of extract (determined by the method of Bradford) were diluted in $100 \mu \mathrm{l}$ ICE standard buffer (100 mM HEPES-KOH, pH 7.5, 10\% sucrose, 0.1\% CHAPS, $10 \mathrm{mM}$ DTT, $0.1 \%$ BSA) containing $50 \mu \mathrm{M}$ DEVD-pNA or VEID-pNA, respectively.

The enzymatic reactions were carried out in a microtiter plate for $45 \mathrm{~min}$ at $37^{\circ} \mathrm{C}$. Absorbance was measured at $405 \mathrm{~nm}$ in a microtiter plate-reader and the specific activity was calculated using $\mathrm{p}$ nitroaniline as a standard.

\section{Subcellular fractionation}

Cells were grown in $10 \mathrm{~cm}$ diameter petri disks in McCoy $5 \mathrm{~A}$ medium containing $5 \%$ Hyclone calf serum for 5 days reaching confluency. They were then treated with either $0.1 \mu \mathrm{M}$ TPA or $100 \mu \mathrm{M}$ ATP, respectively, for the indicated times. Afterwards the disks were rinsed twice with ice cold PBS. Cells were scraped with a rubber policeman into $400 \mu \mathrm{l} 250 \mathrm{mM}$ sucrose, $25 \mathrm{mM}$ Tris-Cl, pH 7.5, $2 \mathrm{mM}$ DTT, $5 \mathrm{mM}$ EDTA, $0.1 \mathrm{mM}$ sodium orthovanadate, $10 \mathrm{nM}$ okadaic acid, protease inhibitor mix 'complete, EDTA-free' (Boehringer, Mannheim, Germany). Cells were disrupted for $10 \mathrm{~s}$ with a mini ultra turrax. A cytosolic extract was prepared by centrifugation for $30 \mathrm{~min}$ at $100000 \times \mathrm{g}$. To the supernatant (cytosol) $2 \%$ SDS and $2 \%$ mercaptoethanol were added. The pellet was extracted with the above buffer without sucrose, but containing $1 \%$ Triton $X-100$. The extract was clarified by centrifugation for $10 \mathrm{~min}$ at $13000 \times \mathrm{g}$. To this supernatant (membrane fraction) $2 \%$ SDS and $2 \%$ mercaptoethanol were added. Aliquots of $10 \mu \mathrm{g}$ protein were used for Western blot analysis of PKCisoforms.

\section{Uptake of ethidiumbromide}

Cells were grown in McCoy medium containing 5\% Hyclone calf serum on $22 \mathrm{~mm}$ diameter slides for 5 days reaching confluency. The slides were then mounted into a home built incubator attached to a Leica DMIRB inverted microscope. The McCoy medium was then replaced by serum free MCDB 402 medium containing $100 \mu \mathrm{M}$ ATP. Two $\mu \mathrm{g} / \mathrm{ml}$ ethidiumbromide was added either immedately after serum exchange or $1 \mathrm{~h}$ later. Cells were monitored over a time span of $30 \mathrm{~min}$ after the addition of ethidiumbromide using phase contrast and red fluorescence.

\section{Acknowledgements}

The excellent technical assistance of Christine Troll is gratefully acknowledged. This work was supported by grants from the DGF (SFB 176 TP A10 to J. Hoppe and Sa568/2-1 to A. Sachinidis).

\section{References}

1. Susin SA, Zamzami N, Castedo M, Daugas E, Wang HG, Geley S, Fassy F, Reed JC and Kroemer G (1997) The central executioner of apoptosis: multiple connections between protease activation and mitochondria in Fas/APO-1/ CD95- and ceramide-induced apoptosis. J. Exp. Med. 186: 25-37

2. Barinaga $M$ (1996) Forging a path to cell death. Science 273: 735-737

3. Bortner CD, Oldenburg NBE and Cidlowski JA (1995) The role of DNA fragmentation in apoptosis. Trends Cell Biol. 5: 21-26

4. Kumar S (1995) ICE-like proteases in apoptosis. Trends Biochem. Sci. 20: 198 202

5. McConkey DJ and Orrenius S (1994) Signal transduction pathways to apoptosis. Trends Cell Biol. 4: 370-375

6. Martin SJ, Green DR and Cotter TG (1994) Dicing with death: dissecting the components of the apoptosis machinery. Trends Biochem. Sci. 19: 26-30

7. Osborne B and Schwartz LM (1994) Essential genes that regulate apoptosis. Trends Cell Biol. 4: 394-399

8. Steller H (1995) Mechanisms and genes of cellular suicide. Science 267: 14451449

9. Whyte M (1996) ICE/CED-3 proteases in apoptosis. Trends Cell Biol. 6: 245248

10. Fraser A and Evan G (1996) A license to kill. Cell 85: 781-784

11. Gajewski TF and Thompson CB (1996) Apoptosis meets signal transduction: elimination of a BAD influence. Cell 87: 589-592

12. van de Craen $M$, Vandenabeele $P$, Declerq $W$, van den Brande $I$, van Loo G, Molemans F, Schotte P, van Criekinge W, Beyaert R and Fiers W (1997) Characterization of seven murine caspase familiy members. FEBS Lett. 403 61-69

13. Nicholson DW and Thornberry NA (1997) Caspases: killer proteases. Trends Biol. Sci. 22: 299-206

14. Martins LM and Earnshaw WC (1997) Apoptosis: alive and kicking in 1997. Trends Cell Biol. 7: 111-114

15. Kluck RM, Bossy Wetzel E, Green DR and Newmeyer DD (1997) The release of cytochrome c from mitochondria: a primary site for $\mathrm{Bcl}-2$ regulation of apoptosis. Science 275: 1132-1136

16. Liu X, Kim CN, Yang J, Jemmerson R and Wang X (1996) Induction of apoptotic program in cell-free extracts: requirement for dATP and cytochrome c. Cell 86: $147-157$

17. Yang J, LiuX, BhallaK, Kim CN, Ibrado AM, Cai J, Peng TI, Jones DP and Wang X (1997) Prevention of apoptosis by Bcl-2: release of cytochrome $\mathrm{C}$ from mitochondria blocked. Science 275: 1129-1132

18. Susin SA, Zamzami N, Castedo M, Hirsch T, Marchetti P, Macho A, Daugas E, Geuskens M and Kroemer G (1996) Bcl-2 inhibits the mitochondrial release of an apoptogenic protease. J. Exp. Med. 184: 1331-1341

19. Nunez G and Clarke MF (1994) The Bcl-2 family of proteins: regulators of cell death and survival. Trends Cell Biol. 4: 399-403

20. Wang HG, Rapp UR and Reed JC (1996) Bcl-2 targets the protein kinase Raf-1 to mitochondria. Cell 87: 629-638

21. Zha J, Harada H, Yang E, Jockel J and Korsmeyer SJ (1996) Serine phosphorylation of death agonist $B A D$ in response to survival factor results in binding to 14-3-3 not BCL-X(L). Cell 87: 619-28

22. Tamm I, Kikuchi T and Zychlinsky A (1991) Acidic and basic fibroblast growth factors are survival factors with distinctive activity in quiescent BALB/C 3T3 murine fibroblasts. Proc. Natl. Acad. Sci. USA 88: 3372-3376

23. Tamm I and Kikuchi T (1991) Activation of signal transduction pathways protects quiescent Balb/c-3T3 fibroblasts against death due to serum deprivation. J. Cell Physiol. 148: 85-95

24. Tamm I, Kikuchi T, Krueger J and Murphy JS (1992) Dissociation between early loss of actin fibres and subsequent cell death in serum-deprived quiescent Balb/ c-3T3 cells. Cell Signal 4: 675-686

25. Tamm I and Kikuchi T (1993) Multiple pathways lead to activation of the survival mechanismin quiescentBALB/c-3T3 cells. Proc. Soc. Exp. Biol. Med. 202:174180 
26. Simm A, Hoppe V, Gazit A and Hoppe J (1994) Platelet-derived growth factor isoforms prevent cell death during starvation of AKR-2B fibroblasts. J. Cell. Physiol. 160: 295-302

27. Simm A, Bertsch G, Frank H, Zimmermann U and Hoppe J (1997) Cell death of AKR-2B fibroblasts after serum removal: a process between apoptosis and necrosis. J. Cell Sci. 110: 819-828

28. Heurteaux C, Lauritzen I, Widmann C and Lazdunski M (1995) Essential role of adenosine, adenosine $A 1$ receptors, and ATP-sensitive $K+$ channels in cerebral ischemic preconditioning. Proc. Natl. Acad. Sci. USA 92: 4666-4670

29. Yao Y, Sei Y, Abbracchio MP, Jiang JL, Kim YC and Jacobson KA (1997) Adenosine $A 3$ receptor agonists protect $\mathrm{HL}-60$ and $\mathrm{U}-937$ cells from apoptosis induced by $A 3$ antagonists. Biochem. Biophys. Res. Commun. 232: 317-322

30. Abbracchio MP, Rainaldi G, Giammarioli AM, Ceruti S, Brambilla R, Cattabeni F Barbieri D, Franceschi C, Jacobson KA and Malorni W (1997) The A3 adenosine receptor mediates cell spreading, reorganization of actin cytoskeleton, and distribution of Bcl-XL: studies in human astroglioma cells. Biochem. Biophys. Res. Commun. 241: 297-304

31. Huang N, Wang DJ and Heppel LA (1989) Extracellular ATP is a mitogen for 3 T3 $3 T 6$, and A431 cells and acts synergistically with other growth factors. Proc. Natl. Acad. Sci. USA 86: 7904-7908

32. Gonzalez FA, Bonapace E, Belzer I, Friedberg I and Heppel LA (1989) Two distinct receptors for ATP can be distinguished in Swiss 3 T6 mouse fibroblasts by their desensitization. Biochem. Biophys. Res. Commun. 164: 706-713

33. Gonzalez FA, Rozengurt E and Heppel LA (1989) Extracellular ATP induces the release of calcium from intracellular stores without the activation of protein kinase $C$ in Swiss 3T6 mouse fibroblasts. Proc. Natl. Acad. Sci. USA 86: $4530-$ 4534

34. Ishikawa S, Kawasumi M, Kusaka I, Komatsu N, Iwao N and Saito T (1994) Extracellular ATP promotes cellular growth of glomerular mesangial cells mediated via phospholipase C. Biochem. Biophys. Res. Commun. 202: 234 240

35. Di Virgilio F, Chiozzi P, Falzoni S, Ferrari D, Sanz JM, Venketaraman V and Baricordi OR (1998) Cytolytic P2X purinoceptors. Cell Death Diff. 5: 191-199

36. Schäfer R, Karbach D and Hoppe J (1998) Multiple intracellular pathways interfere with the activation of a CPP32-like protease induced by serum deprivation of AKR-2B cells. Exp. Cell. Res. 240: 28-39

37. Murgia M, Hanau S, Pizzo P, Rippa M and Di Virgilio F (1993) Oxidized ATP. An irreversible inhibitor of the macrophage purinergic $\mathrm{P} 2 \mathrm{Z}$ receptor. J. Biol. Chem. 268: 8199-8203

38. Karenberg TA, Fenn A, Sachinidis A and Hoppe J (1994) The differential activation of phosphatidylinositol-3 kinase and mitogen-activated protein kinases by PDGF-AA and IGF-I might explain the synergistic effect of the two growth factors on the proliferation of AKR-2B fibroblasts. Exp. Cell Res. 213: $266-274$

39. Communi D, Govaerts C, Parmentier M and Boeynaems JM (1997) Cloning of a human purinergic P2Y receptor coupled to phospholipase $C$ and adenyly cyclase. J. Biol. Chem. 272: 31969-31973

40. Murgia M, Pizzo P, Steinberg TH and Di Virgilio F (1992) Characterization of the cytotoxic effect of extracellular ATP in J774 mouse macrophages. Biochem. J. 288: $897-901$

41. Pizzo P, Murgia M, Zambon A, Zanovello P, Bronte V, Pietrobon D and Di Virgilio $F$ (1992) Role of P2z purinergic receptors in ATP-mediated killing of tumor necrosis factor (TNF)-sensitive and TNF-resistant L929 fibroblasts. J. Immunol. 149: $3372-3378$

42. Olivier AR and Parker PJ (1992) Identification of multiple PKC isoforms in Swiss 3T3 cells: differential down-regulation by phorbol ester. J. Cell Physiol. 152 240-244
43. Olivier AR and Parker PJ (1994) Bombesin, platelet-derived growth factor, and diacylglycerol induce selective membrane association and down-regulation of protein kinase C isotypes in Swiss 3T3 cells. J. Biol. Chem. 269: 2758-2763

44. Dekker LV and Parker PJ (1994) Protein kinase C - a question of speciticity. Trends Biochem. Sci. 19: 73-77

45. Seger R, Ahn NG, Boulton TG, Yancopoulos GD, Panayotatos N, Radziejewska E, Ericsson L, Bratlien RL, Cobb MH and Krebs EG (1991) Microtubuleassociated protein 2 kinases, ERK1 and ERK2, undergo autophosphorylation on both tyrosine and threonine residues: implications for their mechanism of activation. Proc. Natl. Acad. Sci. USA 88: 6142-6146

46. Avruch J, Zhang XF and Kyriakis JM (1994) Raf meets Ras: completing the framework of a signal transduction pathway. Trends Biochem. Sci. 19:279-283

47. Chen RH, Chung J and Blenis J (1991) Regulation of pp90rsk phosphorylation and S6 phosphotransferase activity in Swiss 3T3 cells by growth factor-, phorbol ester-, and cyclic AMP-mediated signal transduction. Mol. Cell Biol. 11: 1861 1867

48. Ferrari S, Bannwarth W, Morley SJ, Totty NF and Thomas G (1992) Activation of p70s6k is associated with phosphorylation of four clustered sites displaying Ser/ Thr-Pro motifs. Proc. Natl. Acad. Sci. USA 89: 7282-7286

49. Hoppe J, Hoppe V, Karenberg TA, Fenn A, Simm A and Sachinidis A (1994) Differential activation by platelet-derived growth factor-BB of mitogen activated protein kinases in starved or nonstarved AKR-2B fibroblasts. J. Cell. Physiol. 161: $342-350$

50. Abbracchio MP and Burnstock G (1994) Purinoceptors: are there families of $P 2 X$ and P2Y purinoceptors? Pharmacol. Ther. 64: 445-475

51. Buell G, Collo G and Rassendren F (1996) P2X receptors: an emerging channel family. Eur. J. Neurosci. 8: 2221-2228

52. Fredholm BB, Abbracchio MP, Burnstock G, Dubyak GR, Harden TK, Jacobson KA, Schwabe U and Williams M (1997) Towards a revised nomenclature for P1 and $P 2$ receptors. Trends Pharmacol. Sci. 18: 79-82

53. Brake AJ and Julius D (1996) Signaling by extracellular nucleotides. Ann. Rev. Cell Dev. Biol. 12: 519-541

54. Hoppe J, Weich HA and Eichner W (1989) Preparation of biologically active platelet-derived growth factor type BB from a fusion protein expressed in Escherichia coli. Biochemistry 28: 2956-2960

55. Hoppe J, Weich HA, Eichner W and Tatje D (1990) Preparation of biologically active platelet-derived growth factor isoforms $A A$ and $A B$. Preferential formation of. Eur. J. Biochem. 187: 207-214

56. Shipley GD, Childs CB, Volkenant ME and Moses HL (1984) Differential effects of epidermal growth factor, transforming growth factor, and insulin on DNA and protein synthesis and morphology in serum-free cultures of AKR-2B cells. Cancer Res. 44: 710-716

57. Sachinidis A, LocherR, Hoppe Jand VetterW (1990) The platelet-derived growth factor isomers, PDGF-AA, PDGF-AB and PDGF-BB, induce contraction of vascular smooth muscle cells by different intracellular mechanisms. FEBS Lett. 275: $95-98$

58. Grynkiewicz G, Poenie M and Tsien RY (1985) A new generation of Ca2+ indicators with greatly improved fluorescence properties. J. Biol. Chem. 260: $3440-3450$

59. Simm A, Hoppe V, Tatje D, Schenzinger A and Hoppe J (1992) PDGF-AA effectively stimulates early events but has no mitogenic activity in AKR-2B mouse fibroblasts. Exp. Cell Res. 201: 192-199 